\section{Cytotoxicity, Biocompatibility and Biomineralization of a New Ready- for-Use Bioceramic Repair Material}

Francine Benetti ${ }^{1,2}{ }^{\mathbb{D}}$, Índia Olinta de Azevedo Queiroz ${ }^{1} \mathbb{D}$, Leopoldo CosmeSilva ${ }^{1} \mathbb{B}$, Leticia Citelli Conti ${ }^{1} \mathbb{B}^{-}$, Sandra Helena Penha de Oliveira ${ }^{3} \mathbb{B}$, Luciano Tavares Angelo Cintra ${ }^{1}$ (i)
'Endodontics, School of Dentistry, UNESP - Universidade Estadual Paulista, Araçatuba, SP, Brazil ${ }^{2}$ Restorative Dentistry, School of Dentistry, UFMG - Universidade Federal de Minas Gerais, Belo Horizonte, MG, Brazil ${ }^{3}$ Basic Science, School of Dentistry, UNESP - Universidade Estadual Paulista, Araçatuba, SP, Brazil

Correspondence: Dr. Luciano Tavares Angelo Cintra, Rua José Bonifácio, 1193, 16015-050 Araçatuba, SP, Brasil. Tel: +55-18-3636-2867. e-mail: luciano.cintra@unesp.br

Key Words: biocompatible materials, cytotoxicity, dental materials, endodontics, materials testing.

\section{Introduction}

Although it is a material with high biocompatibility (1) and is widely used for various applications, such as furcation or root perforation treatment, internal or external reabsorption treatment, retrofilling in apical microsurgery, pulp capping, apexification, apexogenesis and pulpotomy (2), mineral aggregated trioxide (MTA) presents some drawbacks (2). One of these drawbacks is that it is difficult to handle as it is supplied in powder form for agglutination in distilled water, resulting in a material with a sandy consistency $(1,2)$. To overcome these drawbacks, different vehicles for applying the material and MTA formulations are constantly being studied (1). Recently, MTA Repair High-Plasticity (MTA-HP ${ }^{\circledR}$; Angelus Indústria de Odontológicos S/A, Londrina, PR, Brazil) was introduced, wherein manufacturers replaced the distilled water accompanying the MTA with a plasticizer liquid, thus increasing its plasticity $(1,3,4)$. The MTA-HP showed excellent biological properties compared to its precursor, white MTA-Angelus ${ }^{\circledR}$ (MTA-Ang; Angelus Indústria de Odontológicos $S / A)(1)$, along with better push-out bond strength (3) and slightly higher $\mathrm{pH}$ (4).
However, the search for a more easily handled material is constant, and for this, a new formulation of a readyto-use bioceramic reparative material was developed. This experimental material is called Bioceramic (Bio-C) Repair (Angelus Indústria de Odontológicos $\mathrm{S} / \mathrm{A}$ ), and it is not provided in powder-and-liquid form; instead, it is offered as a single product stored in a syringe, thereby eliminating the need to manipulate the material. The applications for Bio-C Repair are the same as for MTA $(1,2)$.

According to the manufacturer, the material's composition includes calcium silicate, calcium oxide, zirconium oxide, iron oxide, silicon dioxide and a dispersing agent (Table 1). Several studies have shown that the addition of zirconium oxide to calcium silicate material increases compressive strength (5), promotes greater antimicrobial activity (6) and induces cell proliferation (7). However, the Bio-C Repair is not yet available in the market, and the biocompatibility and biomineralization capacity of this material had not been tested to determine if it could be suggested as a substitute for MTA.

To evaluate the biological response of new materials, studies with polyethylene tubes containing the material 
to be evaluated in subcutaneous tissue of rats or with cell culture, can be used $(1,8)$. This in vivo method allows to simulate the clinical condition, where the material is directly in contact with the tissue $(1,8)$. While in vitro methods with cell culture allows a simple and quick comparison between the materials, showing the effects of the compounds released by theses on the cells $(1,8)$. Thus, this study evaluated Bio-C Repair's cytotoxicity to fibroblast cells, its biocompatibility and its ability to induce mineralization compared to the recently introduced MTA$\mathrm{HP}$ and the precursor, white MTA-Ang, in the subcutaneous tissue of rats. The null hypothesis was adopted: it is expected that these materials exhibit no differences in cytotoxicity, biocompatibility and biomineralization

\section{Material and Methods}

\section{Cytotoxicity Analysis on Culture of Fibroblasts Preparation of Material Extracts}

Three materials were used in this study: the Bio-C Repair was acquired in a ready-to-use formula, and the MTA-HP and white MTA-Ang were mixed according to the manufacturers' instructions.

The material discs were prepared under aseptic conditions as previously described $(1,8)$. The discs were molded in a sterile cylindrical polyethylene tube (diameter: $5 \mathrm{~mm}$; height: $3 \mathrm{~mm}$ ), kept in an incubator at $37^{\circ} \mathrm{C}$ for $6 \mathrm{~h}$ to achieve complete setting and then sterilized by ultraviolet irradiation for $1 \mathrm{~h}$; the preparation of material extracts was performed according to previous studies and according to ISO 10993-5:2009 (1,8,9). Undiluted extracts $(1 / 1)$ and two dilutions ( $1 / 2$ and $1 / 4)$ of each of the three materials were used in this study $(8,9)$.

\section{Cytotoxicity Test}

Fibroblast-like cells (L929; CRL-6364; ATCC, Manassas,
Va., USA) were cultured in Dulbecco's Modified Eagle Medium (DMEM) supplemented by 10\% fetal bovine serum, penicillin and streptomycin under standard cell-culture conditions $\left(37^{\circ} \mathrm{C}, 100 \%\right.$ humidity, 95\% air, 5\% $\mathrm{CO}_{2}$ ). The cells were seeded at the desired density $\left(10^{4}\right.$ cells/well) in 96-well plates and incubated for $24 \mathrm{~h}$ under standard cellculture conditions to achieve cell attachment before adding the extracts. The cultures then underwent serial extract dilution (undiluted, 1/2 and 1/4). L929 fibroblasts cultured in DMEM without any extracts were used as a control. At 6,24 and $48 \mathrm{~h}$, the cell viability was determined using a 3-(4,5-dimethylthiazol-2-yl)-2,5-diphenyltetrazolium bromide (MTT) assay. At each time point, an MTT solution (Sigma-Aldrich, St. Louis, MO, USA) was added to the cells and the fibroblasts were incubated at $37{ }^{\circ} \mathrm{C}$ for $4 \mathrm{~h}$, shielded from light. The MT solution was then discarded, and $200 \mu \mathrm{L}$ of isopropyl alcohol was added to each well. The plate was kept under continuous agitation for $30 \mathrm{~min}$ to dissolve the dark blue crystals. The blue solution was then transferred to a 96-well plate to measure the optical density at $570 \mathrm{~nm}$ using a spectrophotometer (Shimadzu MultSpec-1501; Shimadzu Corporation, Chiyoda, Tokyo, Japan). Each condition was analyzed in triplicate and according to the ISO 10993-5 (9).

\section{Biocompatibility and Biomineralization Assay on Subcutaneous Tissues}

Sixteen healthy male rats (Rattus albinus, Wistar) with an age of 2 months, weighing approximately $280 \mathrm{~g}$, were used. The sample size was established based on previous research $(1,8)$. The animals were kept in an environment with a temperature between 22 and $24{ }^{\circ} \mathrm{C}$ and a controlled light cycle (12 light $h$ and 12 dark $h$ ), with access to food and water ad libitum, and collective cages. The animals were observed during the whole period of the experiment. This study was approved and performed according to the relevant guidelines of the institutional Ethical Committee of local (CEUA 9372017).

Polyethylene tubes (four per rat; Abbott Laboratories of Brazil, Sao Paulo, SP, Brazil) were filled with Bio-C Repair (ready to use), MTA-HP or MTA-Ang (prepared according to the manufacturers' 
recommendations), or they were left empty as a control. The surgical procedure was performed according to a previous study (1): the rats were anesthetized by intramuscular injections of ketamine $(80 \mathrm{mg} / \mathrm{kg}$. Francotar; Virbac do Brasil Ind e Com Ltda; Roseira, SP, Brazil) and xylazine (10 $\mathrm{mg} / \mathrm{kg}$, Rompum; Bayer SA, São Paulo, SP, Brazil), and their dorsa were shaved and a $2.0-\mathrm{cm}$ incision was made in a head-to-tail orientation with a \# 15 Bard-Parker blade (BD, Franklin Lakes, NJ, USA). The skin was reflected to create two pockets on the right side and two pockets on the left side of the incision. After the randomly selected tubes were implanted into the pockets, the skin was closed with 4-0 silk sutures.

After 7 and 30 days ( $n=8$ tubes per group), the rats were killed with an overdose of an anesthetic solution. The implanted tubes, along with the surrounding tissue, were removed and fixed in a 10\% formalin solution at a $\mathrm{pH}$ of 7.0. The fixed specimens were processed and embedded in paraffin and serially sectioned into 5-mm cuts to prepare for hematoxylin-eosin staining.

Inflammatory reaction of the tissues that were in contact with the material on the open end of the tubes were scored, according to previous studies $(1,8)$, as follows: 1 , no or few inflammatory cells and no reaction; 2 , fewer than 25 cells and mild reaction; 3 , between 25 and 125 cells and moderate reaction; 4,126 or more cells and severe reaction. In addition, these scores were also applied to the separate counting of macrophages $(10,11)$. The amount of fibroblasts was evaluated through the application of scores adapted from Garcia et al. $(10,11)$, as follows: 1 , no or few fibroblasts; 2 , fewer than 25 fibroblasts; 3 , between 25 and
125 fibroblasts; 4,126 or more fibroblasts. All analyses were performed using magnification of $400 x$ in center on the open of the tube. Fibrous capsules were considered thin if $<150 \mu \mathrm{m}$ and thick if $\geq 150 \mu \mathrm{m}$. The von Kossa positive structures or birefringent structures under polarized light were recorded as either present or absent (1). All data were analyzed by a single calibrated operator in a blind manner under light microscopy (DM 4000 B; Leica Microsystem, Wetzlar, Germany).

\section{Statistical Analysis}

Cytotoxicity data were statistically analyzed by twoway ANOVA, followed by Bonferroni correction using the Graph Pad Prism (version 5.0) software program, after the Shapiro-Wilk normality test. The Kruskal-Wallis test, followed by the Dunn test, was used for biocompatibility data. The P-value was considered significant at 5\%.

\section{Results}

\section{Cytotoxicity Assay}

The L929 fibroblasts' viability values in the presence of the different material extracts, evaluated by MTT assay at 6, 24 and $48 \mathrm{~h}$, are shown in Figure 1.

The MTT assay revealed that cell viability was higher in the presence of the material extracts (undiluted, $1 / 2$ and $1 / 4$ ) at most of the evaluation times compared to the control group $(\mathrm{p}<0.05)$, except for the undiluted Bio-C extract at 6 and $48 \mathrm{~h}$ and the undiluted MTA-HP and white MTA-Ang extracts at $48 \mathrm{~h}(\mathrm{p}<0.05)$; however, of these extracts, only undiluted white MTA-Ang extract at $48 \mathrm{~h}$ had reduction in cell viability (value of $72.75 \%$ ), but since this reduction

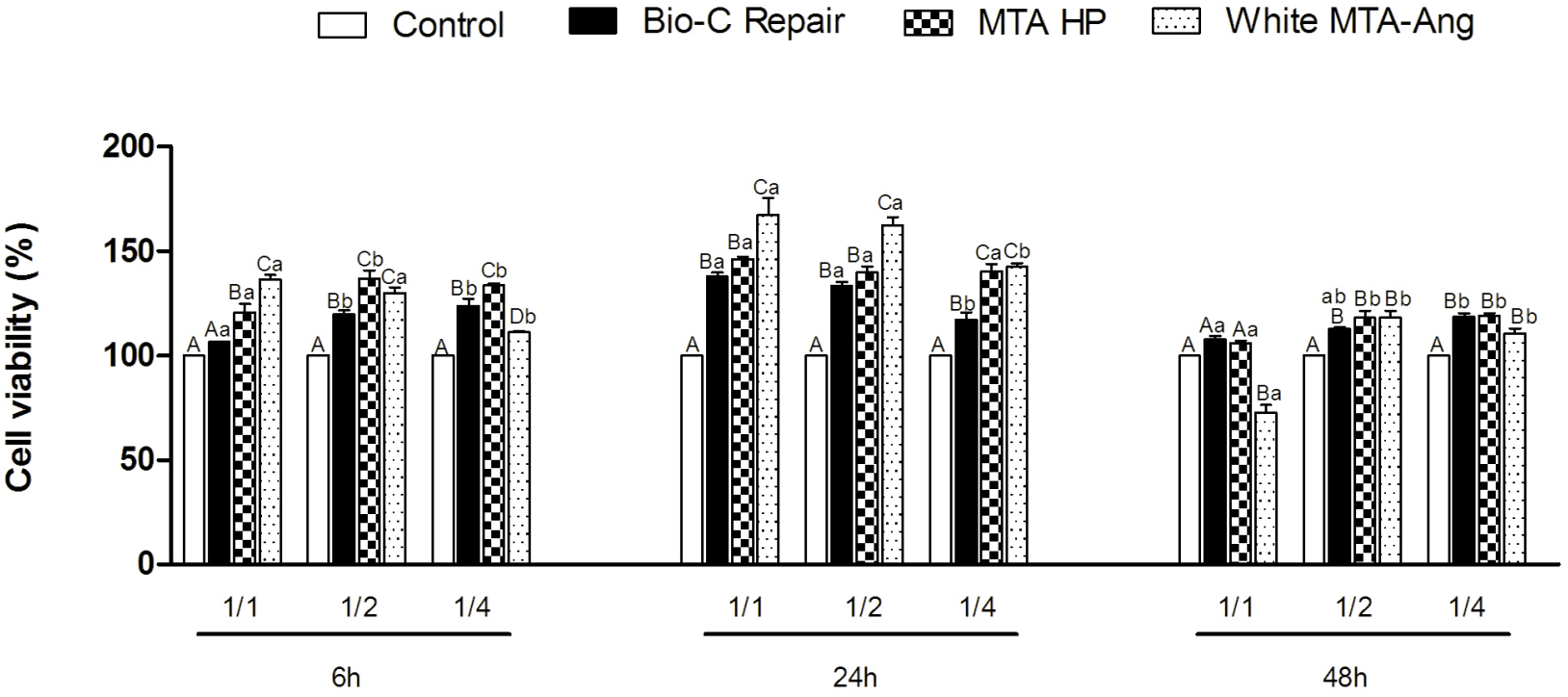

Figure 1 . The effects of material extracts on fibroblast viability after 6, 24 and $48 \mathrm{~h}$, as determined by the MTT assay. The same uppercase letters indicate no statistical differences among the materials at the same period and in the same dilution. The same lowercase letters indicate no statistical differences among extract dilutions of the same material at the same period. 
was not greater than $30 \%$ in relation to the control, it was not considered cytotoxic according to ISO 10993-5:2009 (E) recommendations.

A comparison of the extracts revealed that, at no dilution and $1 / 2$ dilution, the MTA-HP extract showed higher cytocompatibility than the Bio-C Repair extract at $6 \mathrm{~h}$, as well as with the $1 / 4$ dilution at 6 and $24 h(p<0.05)$. The white MTA-Ang extract showed higher cytocompatibility than the Bio-C Repair at 6 and $24 \mathrm{~h}$ with all dilutions $(\mathrm{p}<0.05)$. In addition, the undiluted white MTA-Ang extract increased cell viability at 6 and $24 \mathrm{~h}$ compared to the MTA-HP and the $1 / 2$ diluted extract at $24 \mathrm{~h}(\mathrm{p}<0.05)$.

However, no difference was noted regarding the cytocompatibility of all material extracts at $48 \mathrm{~h}$, except for the undiluted white MTA-Ang, which decreased cell viability compared to the other groups $(p<0.05)$.

\section{Biocompatibility and Biomineralization Analysis}

Rats were healthy on days when the tubes were removed for further processing and histological analysis. The results of the histologic analysis are provided in Table 2 and Figure 2. At 7 days after tube implantation, most of the specimens from the control and Bio-C Repair groups had moderate inflammatory infiltration, principally of neutrophils, lymphocytes and macrophages, and some specimens had mild inflammatory infiltration. The same occurred for the MTA-HP and white MTA-Ang groups; however, at least one specimen from each of the MTA groups showed severe inflammatory infiltration. In separated analysis of macrophages, the most specimens of all groups had mild amount of macrophages at 7 days, that were found surrounding the residual material, or in region of opening of tube. The amount of fibroblasts was mild in Control, MTA HP and white MTA-Ang groups, but the most specimens of Bio-C Repair had moderate amount of fibroblasts. However, these cells were present in a thick and disorganized fibrous capsule. Statistically, there were no differences between groups in the different analyses ( $p>0.05$ ).

At 30 days, most specimens from the control group had mild inflammatory infiltration, whereas others had negligible inflammatory infiltration. Similarly, most specimens from the Bio-C Repair group had mild to absent inflammatory infiltration; however, one specimen had moderate inflammatory infiltration. In the case of the MTA-HP and white MTA-Ang groups, only one specimen from each had no inflammation; most specimens had mild inflammatory infiltration, and at least one specimen had moderate inflammatory infiltration. The inflammatory infiltrate at this period was principally of lymphocytes. Regarding amount macrophages, the most specimens of all group showed absence of macrophages, and if present, were observed in the opening region of the tube in control group, or macrophages were close to the residual materials. The residual materials of all groups were present in the middle of the fibrous capsule, and not only in the opening of the tube. There was an increase in the amount of fibroblasts for all groups at 30 days, mainly for Bio-C Repair; however, the groups were not statistically different $(p>0.05)$. The fibroblasts were found in thin fibrous capsule with the presence of well-structured collagen fibers.

At 7 and 30 days, all the material groups had structures that were positive for von Kossa staining and birefringent to polarized light; the same did not occur in the control group. These positive structures were observed principally scattered in the connective tissue of the fibrous capsule, but some specimens showed the positivity present in the tube opening region. These characteristics were observed both for the von Kossa positive structures, which have darkened coloration in the histological sections, as well as for the birefringent structures analyzed under polarized light.

\section{Discussion}

Most materials that could be used for cavity repair have been made available with the need for operator manipulation $(1,10,11)$. This study investigated a new bioceramic repair material that does not need to be manipulated, ready-to-use Bio-C Repair, and showed that this material presents cytocompatibility, along with a biocompatibility and biomineralization capacity that is similar to MTA-HP and white MTA-Ang, accepting the null hypothesis.

Permanent cell lines, such as the L929 fibroblast lineage, have advantages over cells of primary lineages, such as the capacity for continuous growth (12). Cells of the primary lineage die upon reaching a growth plateau (12). In addition, L929 lineage exhibit metabolic stability, reproduce easily (13) and are recommended by ISO 109935:2009 (9). Regarding in vitro methods, non-diluted extracts and different dilutions of the extracts were used as recommended by the ISO 10993-5:2009 (9) and according to previous study (8). This is because, after the application of the material in the tissue, the leachable compounds are continuously eliminated by the extracellular fluids, their local concentrations getting progressively smaller as represented by the different dilutions used $(8,14)$. Further, undiluted extracts may lead to rapid cell death, especially when the material was not previously tested (14).

One of the differences among the tested materials is the radiopacifier. Zirconium oxide is a radiopacifier in Bio-C Repair, and this study shows that diluted Bio-C Repair extracts induced greater cellular viability compared to the control group at all analyzed times, which demonstrates its excellent cytocompatibility. Previous studies showed that this radiopacifier was associated with cell proliferation 

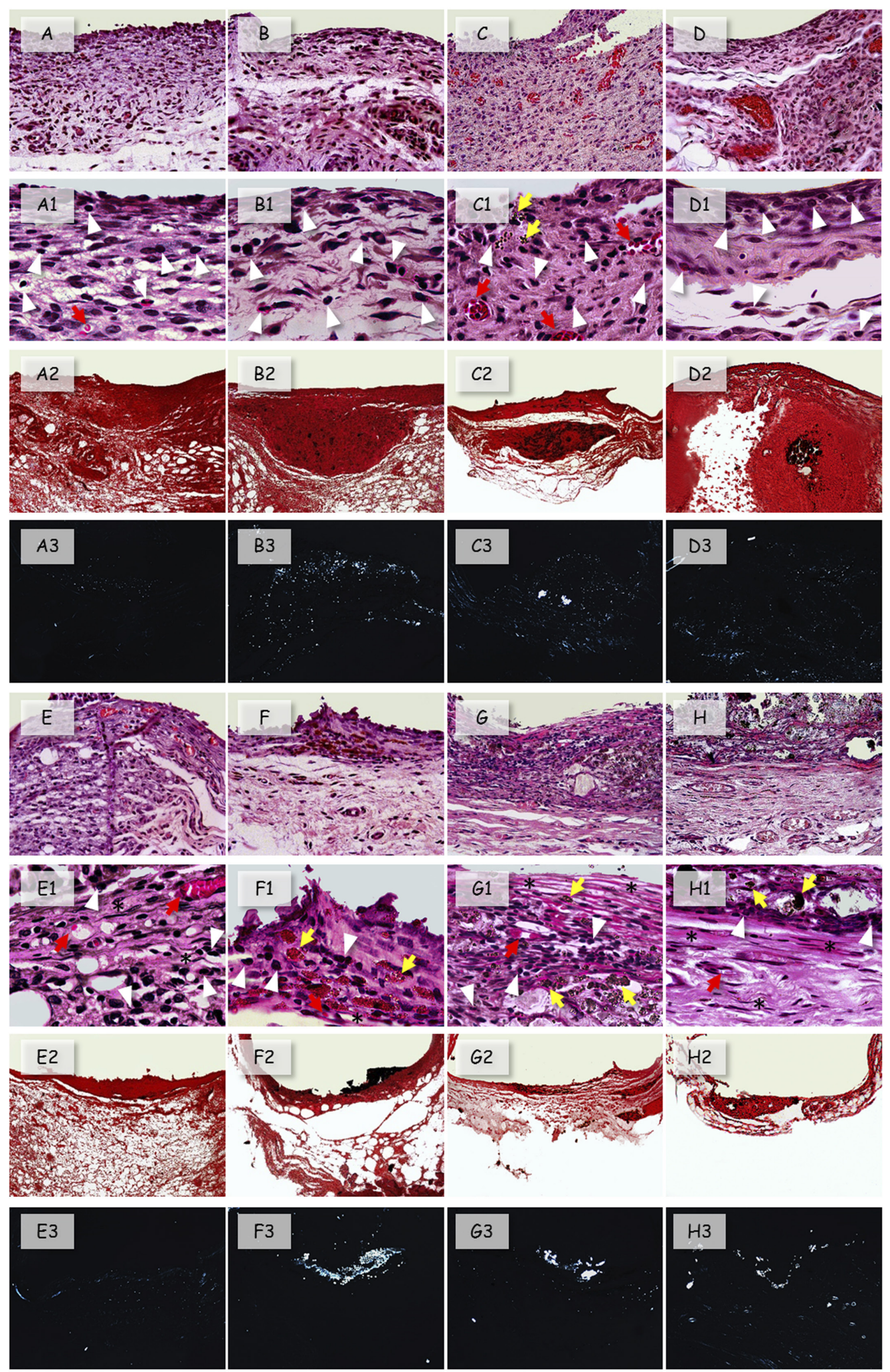

Figure 2. The following are representative images of the biocompatibility and biomineralization of each group. The white arrowheads in the largest magnification point to cells of the inflammatory infiltrate, and the red and yellow arrows point blood vessels and material in the tissue, respectively; the asterisk indicates the collagen fibers of the fibrous capsule. (A-A3; E-E3) Control group: (A, A1) presence of moderate inflammatory cell infiltration and thick fibrous capsule at 7 days and (E, E1) moderate inflammatory infiltration and thin fibrous capsule at 30 days; (A2, E2) absence of positive structures for von Kossa or (A3, E3) birefringent to polarized light. (B-B3; F-F3) Bio-C Repair group, (C-C3; G-G3) MTA-HP group and (D-D3; H-H3) white MTA-Ang group: (B,B1-D,D1) presence of moderate inflammatory cell infiltration and thick fibrous capsule at 7 days and (F,F1-H,H1) mild inflammatory cell infiltration and thin fibrous capsule at 30 days; (B2-D2; F2-H2) presence of positive structures for von Kossa and (B3-D3; F3-H3) birefringent structures to polarized light. [A,A1-D,D1; E,E1-H,H1, Hematoxylin-eosin staining, 400×, 1000x. A2-D2; E2-H2, staining according to the von Kossa technique, 100×. A3-D3; E3-H3, polarized light visualization, 100×] 
(7) which is consistent with our results. However, white MTA-Ang, which had bismuth oxide as a radiopacifier, had greater cytocompatibility in most of the extract dilutions and periods evaluated when compared to Bio-C Repair. Similarly, a previous study showed greater cytocompatibility of white MTA-Ang within $24 \mathrm{~h}$ compared to a calcium silicate material with zirconium oxide (15).

The MTA-HP, whose radiopacifier is calcium tungstate, was another material recently developed with the objective of overcoming the difficult manipulation of the MTA $(1,3)$. In a previous study, MTA-HP showed greater cytocompatibility compared to white MTA-Ang after a period of $72 \mathrm{~h}$ (1). Also, it was seen that MTA-HP promoted human dental pulp stem cell migration, comparable with that of white MTA-Ang (4). In this study, the cell viability induced by MTA-HP was lower than that of its precursor in some dilutions during the initial periods; however, it had a better result compared to white MTA-Ang when the former was more diluted. It should be noted that in vitro studies represent the first level of research and are important for understanding biological risks before using these materials in vivo (16). However, tests with cell cultures have limitations, especially when using two-dimensional cell cultures, as in this study $(8,16)$.

Not only the radiopacifier but also the other compounds of each material, on their nanoscale surfaces, are responsible for the reactions observed with the different materials tested (17). For example, the presence of strontium and aluminum was previously detected in the particles of the MTA-HP (17), which may influence its cytotoxicity or biocompatibility. In addition, MTA-HP was able to release a minimal amount of silicon, while white MTA-Ang revealed a moderate level (4). Studies indicate that silicon ions are released in an aqueous environment and could improve the biological response to the materials (18), being one more factor explaining the superior in vitro response observed with white MTA-Ang. However, studies regarding the release of ions in Bio-C Repair still need to be performed for proper discussion of their properties.

The presence of calcium ions is also essential for tissue therapy and hard tissue formation (8). However, in a previous study, the high calcium content in the MTA-HP particles was not enough to release them in the extracts evaluated (17). These data disagree with the present study, where positive structures for von Kossa and polarized light were observed, which would require the release of calcium into the tissue to occur. In addition, according to Guimarães et al. (19), the properties of calcium silicate cements that are due to the formation of calcium hydroxide associated with the release of calcium ions, which allow the alkalinizing activity, were observed in both white MTA-Ang and MTA-HP (19).

In regard to tissue response, the calcium silicate materials containing zirconium oxide generate less inflammation compared to those containing bismuth oxide (20). However, in the present study there was no significant difference between the white MTA-Ang and Bio-C Repair. Previously, zirconium oxide added to calcium silicate was associated with the significant regression of inflammation occurring in rat subcutaneous tissue compared to white MTA-Ang (7). These results confirm the biocompatibility of calcium silicate-based materials containing zirconium oxide.

Previously, the MTA-HP biocompatibility was similar to that of its precursor, white MTA-Ang, in all periods $(1,21)$, as observed in the present study. This similarity was also observed in relation to Bio-C Repair. In in vitro analysis,

Table 2. Inflammatory infiltrate, macrophages and fibroblasts scores, thickness of fibrous capsule and biomineralization ability of the all groups

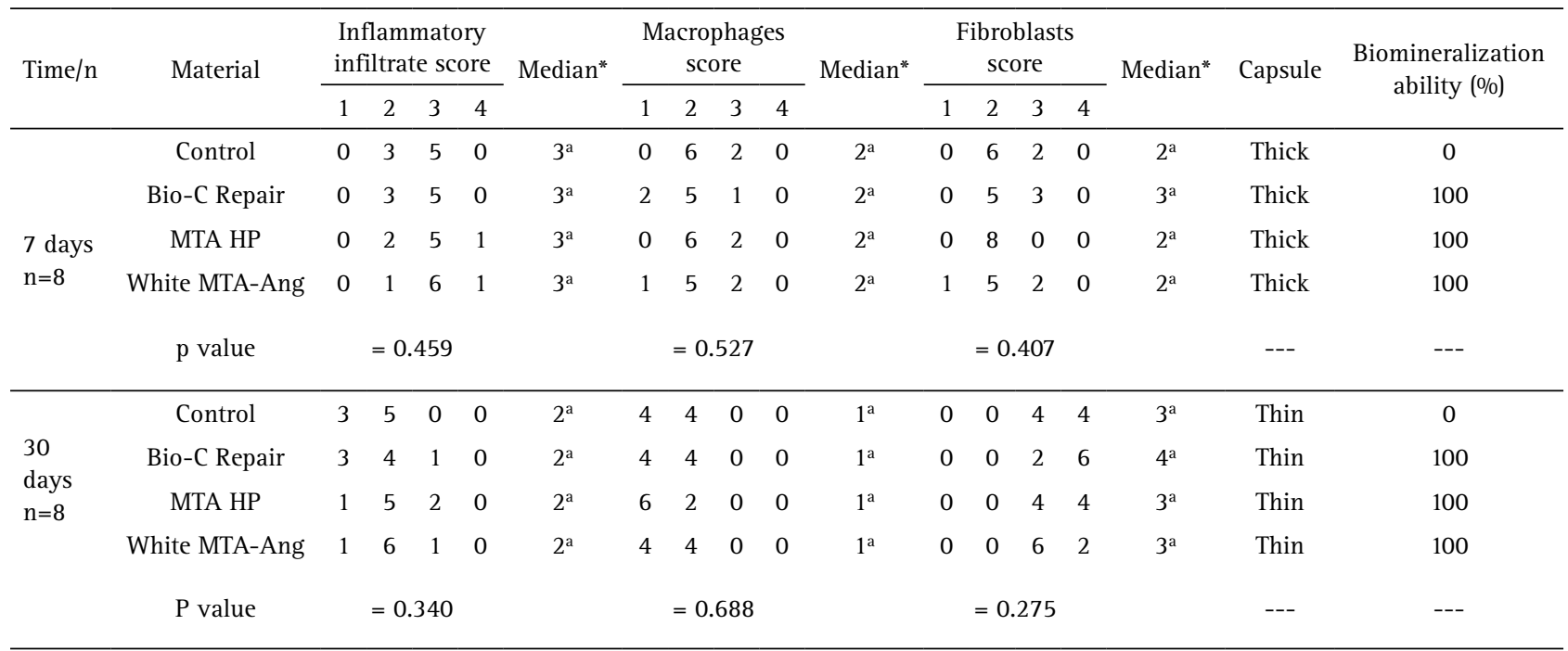

*Same letters indicate no statistical difference among the groups, in according with each analysis ( $\mathrm{p}>0.05)$. 
the cell viability did not differ between the MTA-HP and Bio-C Repair in the periods of 24 and $48 \mathrm{~h}$ with most extract dilutions. The Bio-C Repair and the MTA-HP compositions differ greatly (1). However, both had a radiopacifier advantage in relation to bismuth oxide. In the same way that the presence of zirconium oxide can improve the properties of calcium silicate $(7,20,22)$ the calcium tungstate of the MTA-HP also showed good results, such as a greater release of calcium ions and good cellular viability (23).

The inflammation was observed also in the control group, where the polyethylene tubes were empty. Inflammation was moderate within 7 days and became mild after that. Polyethylene tubes are indicated by ISO because they are inert and do not induce inflammation (24). However, surgical trauma causes inflammation in the tube insertion area, resulting in inflammatory infiltrate (24). Previous studies corroborate our results, showing the inflammation in this group $(1,8,22,24)$, thus the importance of the control group for comparing inflammation levels with the different tested materials that are also influenced by the surgical trauma (24). In this study, the groups had moderate inflammation in the initial period, later becoming mild, similar to the control group. In addition, it is observed in other reports that the inflammation tends to decrease further with longer study durations, being insignificant at 60 and 90 days after the implantation of the empty tubes $(7,24,25)$, as well as of the MTA $(7,25)$, indicating that the same would occur in the present study for these groups. Thus, clinically, tissues are expected to respond positively when in contact with these materials. However, further studies to be carried out with these longer analysis periods could confirm the biocompatibility over time of the new materials tested.

The materials' ability to induce biomineralization was expected. The MTA-based and calcium silicate-based materials showed a considerable release of calcium ions, which can induce hard-tissue formation $(22,25)$. In rat subcutaneous tissue, hard-tissue formation is not observed, but calcite-crystal formation and nuclei mineralization indicate the materials' bioactivity capacity $(1,25)$. In the present study, the analysis under polarized light displayed the presence of calcite crystals in the material groups, and nuclei calcification was observed through the von Kossa staining. A previous study has shown that MTA-HP had comparable ability to white MTA-Ang (1); however, the present study adds that Bio-C Repair also exhibits bioactivity and can fulfill its intended role. This study shows that Bio-C Repair has the basic properties that a repair material needs when it meets living tissue: biocompatibility and biomineralization capacity.

In conclusion, Bio-C Repair showed similar cytocompatibility to MTA-HP and white MTA-Ang. In addition, Bio-C Repair is biocompatible and induces similar biomineralization to MTA-HP and white MTA-Ang.

\section{Resumo}

Novas formulações de agregado de trióxido mineral (MTA) são constantemente introduzidas no mercado, geralmente em forma de pó e líquido. 0 Biocerâmico (Bio-C) Reparador (Repair) é um material pronto para uso sugerido como substituto do MTA, mas suas propriedades precisam ser estudadas. Este estudo avaliou a citotoxicidade, biocompatibilidade e biomineralização do Bio-C Repair comparado ao MTA-High Plasticity (MTA-HP) e MTA branco da Angelus (MTA-Ang). Fibroblastos L929 foram expostos a extratos dos materiais (não diluido, 1/2 e 1/4 diluições; 6,24 e $48 \mathrm{~h}$ ). Tubos de polietileno contendo os materiais ou vazios (controle) foram implantados no tecido subcutâneo de ratos. Após 7 e 30 dias $(n=8)$, os espécimes foram removidos para análises (hematoxilinaeosina, von Kossa e luz polarizada). Os dados da citotoxicidade foram analisados estatisticamente pelo teste de two-way ANOVA, e os dados da biocompatibilidade pelos testes de Kruskal-Wallis e Dunn $(p<0,05)$. As células expostas aos materiais apresentaram maior viabilidade celular na maior parte dos periodos, comparados com o controle $(p<0,05)$. 0 extrato não diluído e $1 / 2$ diluição do MTA-HP apresentaram maior citocompatibilidade do que Bio-C Repair às $6 \mathrm{~h}$, e com 1/4 diluição às $24 \mathrm{~h}$ $(p<0,05)$; o MTA-Ang branco apresentou maior citocompatibilidade do que o Bio-C Repair na maior parte dos periodos $(p<0,05)$. 0 extrato não diluído do MTA-Ang branco apresentou maior citocompatibilidade às 6 e $24 \mathrm{~h}$ comparado ao MTA-HP, e com $1 / 2$ diluição às $24 \mathrm{~h}(\mathrm{p}<0,05)$. A citocompatibilidade dos materiais foi semelhante às $48 \mathrm{~h}$ para a maior parte das diluições $(p>0,05)$. Aos 7 e 30 dias, os grupos apresentaram inflamação moderada e leve, respectivamente $(p>0,05)$. Todos os materiais mostraram estruturas positivas para von Kossa e luz polarizada. Em conclusão, o Bio-C Repair teve citocompatibilidade semelhante aos materiais à base de MTA, é biocompativel e induz à biomineralização.

\section{Acknowledgements}

This study was supported by a grant (305969/2015-3) from the Conselho Nacional de Desenvolvimento Científico e Tecnológico - CNPq.

\section{References}

1. Cintra LTA, Benetti F, de Azevedo Queiroz IOO, de Araújo Lopes JM, Penha de Oliveira SH, Sivieri Araújo G, et al. Cytotoxicity, biocompatibility, and biomineralization of the new high-plasticity MTA Material. J Endod 2017:43:774-778.

2. Parirokh $M$, Torabinejad M. Mineral trioxide aggregate: a comprehensive literature review-part III: clinical applications, drawbacks, and mechanism of action. J Endod 2010;36:400-413.

3. Silva EJ, Carvalho NK, Carvalho NK, Zanon M, Senna PM, De-Deus $\mathrm{G}$, et al. Push-out bond strength of MTA HP, a new high-plasticity calcium silicate-based cement. Braz Oral Res 2016; 30. pii: S180683242016000100269.

4. Tomás-Catalá CJ, Collado-González M, García-Bernal D, Oñate-Sánchez $R E$, Forner $L$, Llena $C$, et al. Comparative analysis of the biological effects of the endodontic bioactive cements MTA Angelus, MTA Repair HP and NeoMTA Plus on human dental pulp stem cells. Int Endod J 2017;50 Suppl 2:e63-e72.

5. Vasques-Garcia F, Tanomaru-Filho M, Chávez-Andrade GM, BossoMartelo R, Basso-Bernardi MI, Guerreiro-Tanomaru JM. Effect of silver nanoparticles on physicochemical and antibacterial properties of calcium silicate cements. Braz Dent J 2016;27:508-514.

6. Espir CG, Guerreiro-Tanomaru JM, Spin-Neto R, Chávez-Andrade GM, Berbert FL, Tanomaru-Filho M. Solubility and bacterial sealing ability of MTA and root-end filling materials. J Appl Oral Sci 2016; 24:121-125.

7. Silva GF, Guerreiro-Tanomaru JM, da Fonseca TS, Bernardi MIB, SassoCerri E, Tanomaru-Filho M, et al. Zirconium oxide and niobium oxide used as radiopacifiers in a calcium silicate-based material stimulate 
fibroblast proliferation and collagen formation. Int Endod J 2017;50 Suppl 2:e95-e108.

8. Cintra LT, Benetti F, de Azevedo Queiroz í, Ferreira LL, Massunari L, Bueno CRE, et al. Evaluation of the cytotoxicity and biocompatibility of new resin epoxy-based endodontic sealer containing calcium hydroxide. J Endod 2017;43:2088-2092.

9. International Organization for Standardization. ISO 10993-5: Biological evaluation of medical devices - Part 5: Tests for in vitro cytotoxicity. Geneva: ISO; 2009.

10. Garcia LF, Huck C, Scardueli CR, de Souza Costa CA. Repair of Bone Defects Filled with New Calcium Aluminate Cement (EndoBinder). J Endod 2015;41:864-870.

11. Garcia LF, Huck C, Menezes de Oliveira L, de Souza PP, de Souza Costa CA. Biocompatibility of new calcium aluminate cement: tissue reaction and expression of inflammatory mediators and cytokines. J Endod. 2014 Dec;40:2024-2029.

12. Key JE, Rahemtulla FG, Eleazer PD. Cytotoxicity of a new root canal filling material on human gingival fibroblasts. J Endod 2006;32:756758.

13. Cotti E, Petreucic V, Re D, Simbula G. Cytotoxicity evaluation of a new resin-based hybrid root canal sealer: an in vitro study. J Endod 2014;40:124-128.

14. Barros J, Costa-Rodrigues J, Lopes MA, Pina-Vaz I, Fernandes MH. Response of human osteoblastic and osteoclastic cells to $\mathrm{AH}$ plus and pulp canal sealer containing quaternary ammonium polyethylenimine nanoparticles. J Endod 2014;40:1149-1155.

15. Slompo C, Peres-Buzalaf C, Gasque KC, Damante CA, Ordinola-Zapata $R$, Duarte $M A$, et al. Experimental calcium silicate-based cement with and without zirconium oxide modulates fibroblasts viability. Braz Dent J 2015;26:587-591.

16. Silva EJ, Carvalho NK, Ronconi CT, De-Deus G, Zuolo ML, Zaia AA. Cytotoxicity profile of endodontic sealers provided by $3 \mathrm{~d}$ cell culture experimental model. Braz Dent J 2016;27:652-656.

17. Tomás-Catalá CJ, Collado-González M, García-Bernal D, Oñate-Sánchez $R E$, Forner L, Llena $C$, et al. Biocompatibility of new pulp-capping
Materials NeoMTA Plus, MTA Repair HP, and Biodentine on human dental pulp stem cells. J Endod 2018;44:126-132.

18. Zhu L, Yang J, Zhang J, Lei D, Xiao L, Cheng $X$, et al. In vitro and in vivo evaluation of a nanoparticulate bioceramic paste for dental pulp repair. Acta Biomater 2014;10:5156-5168.

19. Guimarães BM, Prati $C$, Duarte MAH, Bramante CM, Gandolfi MG. Physicochemical properties of calcium silicate-based formulations MTA Repair HP and MTAVitalcem. J Appl Oral Sci 2018;26:e2017115.

20. Silva GF, Bosso R, Ferino RV, Tanomaru-Filho M, Bernardi MI, GuerreiroTanomaru JM, et al. Microparticulated and nanoparticulated zirconium oxide added to calcium silicate cement: evaluation of physicochemical and biological properties. J Biom Mat Res Part A 2014;102:4336-4345.

21. Benetti F, Gomes-Filho JE, de Araújo Lopes JM, Barbosa JG, Jacinto RC, Cintra LTA. In vivo biocompatibility and biomineralization of calcium silicate cements. Eur J Oral Sci. 2018 Aug;126:326-333.

22. Cosme-Silva L, Gomes-Filho JE, Benetti F, Dal-Fabbro R, Sakai VT, Cintra LTA, et al. Biocompatibility and immunohistochemical evaluation of a new calcium silicate-based cement, Bio-C Pulpo. Int Endod J 2019;52:689-700.

23. Hungaro Duarte MA, Minotti PG, Rodrigues CT, Zapata RO, Bramante $\mathrm{CM}$, Tanomaru Filho $\mathrm{M}$, et al. Effect of different radiopacifying agents on the physicochemical properties of white Portland cement and white mineral trioxide aggregate. J Endod 2012;38:394-397.

24. Valentim D, Bueno CRE, Marques VAS, Vasques AMV, Cury MTS, Cintra LTA, et al. Calcium hydroxide associated with a new vehicle: Psidium cattleianum leaf extracts. Tissue response evaluation. Braz Oral Res 2017;31:e43.

25. Gomes-Filho JE, de Moraes Costa MT, Cintra LT, Lodi CS, Duarte PC, Okamoto $\mathrm{R}$, et al. Evaluation of alveolar socket response to Angelus MTA and experimental light-cure MTA. Oral Surg Oral Med Oral Pathol Oral Radiol Endod 2010;110:e93-e97.

Received December 29, 2018 Accepted February 5, 2019 